\title{
Effect of Obesity on Tissue Factor, Tissue Plasminogen Activator and Plasminogen Activator Inhibitor Among Obese People in Sapele Southern Nigeria
}

\author{
Kingsley Chukwuka Amaihunwa ${ }^{1}$, Emmanuel Asuquo Etim ${ }^{2,{ }^{*}, \text { Everista Odaburhine Osime }}{ }^{3}$, \\ Zacchaeus Awortu Jeremiah $^{4}$ \\ ${ }^{1}$ Department of Medical Laboratory Services, General Hospital Oghara, Oghara, Nigeria \\ ${ }^{2}$ Department of Hematology and Blood Transfusion Science, Federal Medical Center Yola, Yola, Nigeria \\ ${ }^{3}$ Department of Medical Laboratory Science, University of Benin, Benin, Nigeria \\ ${ }^{4}$ Department of Medical Laboratory Science, River State University, Port Harcourt, Nigeria
}

Email address:

emmasuti@yahoo.com (E. A. Etim)

${ }^{*}$ Corresponding author

\section{To cite this article:}

Kingsley Chukwuka Amaihunwa, Emmanuel Asuquo Etim, Everista Odaburhine Osime, Zacchaeus Awortu Jeremiah. Effect of Obesity on Tissue Factor, Tissue Plasminogen Activator and Plasminogen Activator Inhibitor Among Obese People in Sapele Southern Nigeria. Biomedical Sciences. Vol. 7, No. 3, 2021, pp. 81-85. doi: 10.11648/j.bs.20210703.14

Received: August 2, 2021; Accepted: August 11, 2021; Published: August 23, 2021

\begin{abstract}
Background/Objective: Obesity is a medical condition in which adipose tissue accumulates to the extent of having adverse effect on certain procaogulant factors such as: Human Plasminogen Activator Inhibitor (PAI), tissue Plasminogen Activator (t-PA) and Tissue Factor (TF) of adults in Nigeria. This study therefore aims to evaluate the impacts of obesity on PAI, t-PA, and TF in obese adult in Sapele, South-South Nigeria. Materials and Methods: 312 adults with obesity and 103 normal adults (used as controls) with age between 18 and 65 years were enrolled for this study. $4.5 \mathrm{mls}$ of venous blood was collected into EDTA containers for procoagulant activity measurement. Human Plasminogen Activator Inhibitor (PAI-1), Human tissue Plasminogen Activator (t-PA), and Human Tissue Factor (TF) values were determined using Enzyme Linked Immunosorbent Assay (ELISA) methods. Collated data was analyzed using Student's t-test, correlation and one-way ANOVA followed by LSD post-hoc test and results were expressed as mean \pm standard deviation. Results: The BMI (Body Mass Index) of obese subjects and control subjects were $36.82 \pm 0.55 \mathrm{~kg} / \mathrm{m}^{2}$ and $20.43 \pm 0.29 \mathrm{~kg} / \mathrm{m}^{2}$ respectively at $\mathrm{p}<0.001$. t-PA level of obese subject was $344.34 \pm 43.58 \mathrm{pg} / \mathrm{ml}$ while control group had t-PA value of $192.46 \pm 10.65 \mathrm{pg} / \mathrm{ml}$. In addition, PAI of obese people was $367.24 \pm 27.49 \mathrm{pg} / \mathrm{ml}$ and control subject had PAI value of $253.37 \pm 11.11 \mathrm{pg} / \mathrm{ml}$. Human Tissue Factor (TF) of obese subject and control subjects were $93.31 \pm 7.25 \mathrm{pg} / \mathrm{ml}$ and $66.59 \pm 2.76 \mathrm{pg} / \mathrm{ml}$ respectively at $\mathrm{p}<0.01$. Conclusion: The values of Plasminogen Activator Inhibitor, tissue Plasminogen Activator, and Human Tissue Factor were higher in people with obesity when compare with non-obese control group in Sapele Southern Nigeria.
\end{abstract}

Keywords: Obesity, PAI-1, t-PA, Tissue-Factor, Sapele

\section{Introduction}

Obesity is a medical condition in which excess body fat has gathered to the level that produces adverse effect on our health system. [1] Obesity has emerged as a global health problem and one of the leading avoidable causes of mortality worldwide [2]. In the past, obesity was considered as an indication of good health as well as wealth and prosperity until Hippocrates realized that obesity leads to infertility and early mortality [3].

In addition, uncontrolled body weight gain is associated with many chronic diseases such as: Cardiovascular diseases, type 2 diabetes mellitus, asthma, obstructive sleep apnea, cancer, bone diseases etc. There is a rising trend of overweight and obesity in developed and developing countries worldwide resulting in an increased business costs, low productivity and poor health status [1]. A strong positive 
correlation has also been observed between physical activity and weight gain through earlier multiple cross sectional studies [4]. It has been established that this relationship is bidirectional in nature which implies that, obesity discourage physical activity while, inactivity promotes excessive weight gains that leads to obesity resulting in both cardiovascular and diabetic risk in individuals as well as enhances the severity of other risk factors.

Furthermore, in obesity, there is chronic inflammatory state that is characterized by excess fat deposition on endocrine organ. This resultant inflammatory state usually gave rise to upregulated alteration of certain mechanisms that leads to activation of procoagulant factors including Tissue factors, tissue Plasminogen Activator and Plasminogen Activator Inhibitor which can alter the process of coagulation [5].

Tissue factor (TF) is a trans membrane glycoprotein that activates the coagulation pathway by acting as the cell surface receptor for coagulation factor VIIa. TF is also among the cytokine receptor family that are cell surface binding protein and represent major biomarkers of inflammatory processes which is a common episode in obesity. On the other hand, Human tissue Plasminogen Activator (t-PA) is the major plasminogen activator in preadipocytes of mammals and it is 3T3-LI preadipocytes but decreases with cell differentiation.

In addition, the chronic diseases associated with obesity usually results from complicated interphases of genetic and ecosystem factors that alters levels of procoagulant such as: Tissue Factor (TF), Human tissue Plasminogen Activator (tPA) and Plasminogen Activator Inhibitor (PAI). Therefore, it is imperative to analyze the effect of obesity on these procoagulant in Nigeria and this was the impetus for this present study. Furthermore, the relationship between obesity and TF, t-PA, as well as PAI alterations is not well documented in Southern Nigeria in general and Sapele in particular hence, this study aims to evaluate the effects of obesity on these procoagulants in adult obese subjects in Sapele and its environs.

Sapele is a city located in central part of Delta State, South-South Nigeria. It is positioned at a height of 9 meters above sea level at latitude of $5.89^{\circ}$ and a longitude of $5.68^{\circ}$. Sapele has a population of about 174,273 (Population census, 2006) and accommodates different tribes such as: Okpe, Urhobo, Itsekiri, Ibo, Ijaw, Isoko, Hausa, Edo, Yoruba, Ibibio, Nupe, Tiv, Fulani. The common diets in this locality are starch, yam, garri, rice, beans, plantain, palm oil, fish, meat, perewinkle.

It is believed that, providing information on the effects of obesity on the above listed procoagulants will help in formulation of appropriate strategies and program for maximum healthcare to people with obesity in Sapele and indeed Nigeria at large.

\subsection{Inclusion Criteria}

Obese adults who fell within the age ranges of 18 and 65 years and resident in Sapele and its environ were recruited in the study.

\subsection{Exclusion Criteria}

Pregnant women, known hypertensive patient, patient with demonstrable ascites, intra-abdominal masses, malignancy, renal disease, Liver disease, Diabetes mellitus, HIV infection, current oral anticoagulant use, recent surgery ( $<3$ months), and those who refused consent were excluded from this study.

\section{Materials and Methods}

This is a cross sectional and descriptive study carried out at Central Hospital, Sapele, General Hospital, Oghara and Biomed Diagnostic Centre, Sapele. A total of four hundred and fifteen (415) subjects were enrolled for the study. These include three hundred and twelve (312) obese subjects (comprising of 111 males and 201 females), one hundred and three (103) non-obese subjects (comprising 40males and 63 females) used as control.

\subsection{Sample Collection}

Four and half milliliters $(4.5 \mathrm{mls})$ of venous blood was collected from all participant into EDTA container. The blood sample was analyzed within one hour of collection using ELSA method.

\subsection{Ethical Approval}

Ethical Clearance for this study was obtained from the Ethics committee of Central hospital, Sapele Medical Zone, Sapele, on $8^{\text {th }}$ of December, 2016 with Reference number SNZ/A. 31VOL. 3/54. Informed consent was also obtained from individuals as well as completed structured questionnaire.

\subsection{Sample Analysis}

$4.5 \mathrm{mls}$ of venous blood was collected and dispensed into EDTA container. Samples was further allowed to stand and centrifuge at $3000 \mathrm{rpm}$ for 10 minutes to obtain a clear plasma, which was kept at $-20^{\circ} \mathrm{F}$ until time for analysis. The blood sample was analyzed using ELISA method as follows:

\subsection{Tissue Factor Assay}

Hundred microliters $(100 \mu \mathrm{l})$ of standard solution and Sample were added to each well, the blank was left empty and allowed for $90 \mathrm{mins}$ at $37^{\circ} \mathrm{C}$. Then the solution was removed and hundred microliters $(100 \mu 1)$ of biotinylated detection antibody was added, then incubated for $60 \mathrm{mins}$ at $37^{\circ} \mathrm{C}$. Solution was aspirated and the wells washed for 3 times, then hundred microliters $(100 \mu 1)$ of HRP conjugate was added and incubated for $30 \mathrm{mins}$ at $37^{\circ} \mathrm{C}$. Solution was aspirated and washed for 5 times. Ninety microliter $(90 \mu \mathrm{l})$ of substrate reagent was added and incubated for $15 \mathrm{mins}$ at $37^{\circ} \mathrm{C}$, then, fifty microliters $(50 \mu \mathrm{l})$ of stop solution was added. Optical density (OD) of the blank well was set as zero. The absorbance O. D of each well was read at 450nm using a 
micro plate reader and expressed in $\mathrm{pg} / \mathrm{ml}$. The OD value was proportional to the concentration of the measured parameters.

\subsection{Human Tissue Plasminogen Activator Assay}

Hundred microliters $(100 \mu \mathrm{l})$ of standard solution and Sample were added to each well, the blank was left empty and allowed for $90 \mathrm{mins}$ at $37^{\circ} \mathrm{C}$. Then the solution was removed and hundred microliters $(100 \mu 1)$ of biotinylated detection antibody was added, then incubated for $60 \mathrm{mins}$ at $37^{\circ} \mathrm{C}$. Solution was aspirated and the wells washed for 3 times, then hundred microliters $(100 \mu 1)$ of HRP conjugate was added and incubated for $30 \mathrm{mins}$ at $37^{\circ} \mathrm{C}$. Solution was aspirated and washed for 5 times. Ninety microliter $(90 \mu \mathrm{l})$ of substrate reagent was added and incubated for $15 \mathrm{mins}$ at $37^{\circ} \mathrm{C}$, then, fifty microliters $(50 \mu \mathrm{l})$ of stop solution was added. Optical density (OD) of the blank well was set as zero. The absorbance O. D of each well was read at $450 \mathrm{~nm}$ using a micro plate reader and expressed in $\mathrm{pg} / \mathrm{ml}$. The OD value was proportional to the concentration of the measured parameters.

\subsection{Human Plasminogen Activator Inhibitor Assay}

Hundred microliters $(100 \mu \mathrm{l})$ of standard solution and Sample were added to each well, the blank was left empty and allowed for $90 \mathrm{mins}$ at $37^{\circ} \mathrm{C}$. Then the solution was removed and hundred microliters $(100 \mu 1)$ of biotinylated detection antibody was added, then, incubated for $60 \mathrm{mins}$ at $37^{\circ} \mathrm{C}$. Solution was aspirated and the wells washed for 3 times, then hundred microliters $(100 \mu \mathrm{l})$ of HRP conjugate was added and incubated for $30 \mathrm{mins}$ at $37^{\circ} \mathrm{C}$. Solution was aspirated and washed for 5 times. Ninety microliter $(90 \mu \mathrm{l})$ of substrate reagent was added and incubated for $15 \mathrm{mins}$ at $37^{\circ} \mathrm{C}$, then, fifty microliters $(50 \mu \mathrm{l})$ of stop solution was added. Optical density (OD) of the blank well was set as zero. The absorbance O. D of each well was read at 450nm using a micro plate reader and expressed in $\mathrm{pg} / \mathrm{ml}$. The OD value was proportional to the concentration of the measured parameters.

\section{Data Analysis}

Data analysis was done using Microsoft Excel 2010 and Statistical Package for Social Sciences (IBM SPSS) version 21.0 software. The collated results were expressed as mean and standard deviation. Inferential analysis adopted include: Student's t-test, correlation and one-way analysis of variance (ANOVA) followed by least significant different (LSD) posthoc test for the obese. Correlation between two variables was done using Pearson's linear regression analysis. Statistical significance was set.

\section{Results}

Evaluation of Mean \pm SEM of certain tissue Plasminogen Activator antigen (t-PA), Plasminogen activator inhibitor antigen (PAI) and Tissue factor (TF) among obese and normal weight subject reveals that, obese subjects had significantly higher values of tissue plasminogen activator antigen (tPA), plasminogen activator inhibitor antigen (PAI) and tissue factor at $\mathrm{P}<0.01$ when compared with normal weight subjects as shown in table 1 .

Table 1. tPA, PAI and TF values among obese and normal weight subjects.

\begin{tabular}{llll}
\hline Parameter & Obese $(\mathbf{n}=\mathbf{3 1 2})$ Mean \pm SEM & Normal $(\mathbf{n}=\mathbf{1 0 3})$ Mean \pm SEM & t value \\
\hline tPA $(\mathrm{pg} / \mathrm{ml})$ & $344.34 \pm 43.58$ & $192.46 \pm 10.65$ & 2.659 \\
PAI $(\mathrm{pg} / \mathrm{ml})$ & $367.24 \pm 27.49$ & $253.37 \pm 11.11$ & 3.106 \\
TF $(\mathrm{pg} / \mathrm{ml})$ & $93.31 \pm 7.25$ & $66.59 \pm 2.76$ & 2.771 \\
\hline
\end{tabular}

$* *$ Significant $(\mathrm{p}<0.01) *$ Significant $(\mathrm{p}<0.05) \dagger$ Not Significant

Furthermore, the values of tPA, PAI, and TF, among obese subjects were significantly higher in age groups of 20-29 and $30-39$ years at $\mathrm{P}<0.05$ when matched with control results and no significant difference was observed among those of age greater than 40 years at $\mathrm{P}<0.05$ when compared with control subjects as shown in table 2 .

Table 2. Comparison of Mean \pm SEM of tPA, PAI, and TF values between Obese and Control within the ages brackets of 20-29, 30-39, 40-49 and $\geq 50$

\begin{tabular}{lllll}
\hline Variables & Obese $(\mathbf{n}=\mathbf{3 1 2})$ & Normal $(\mathbf{n}=\mathbf{1 0 3})$ & t-test & p-value \\
\hline $20-29$ years & Mean \pm SEM & Mean \pm SEM & & $0.003^{* *}$ \\
tPA $(\mathrm{pg} / \mathrm{ml})$ & $\mathrm{n}=75$ & $\mathrm{n}=22$ & & $0.001^{* *}$ \\
PAI $(\mathrm{pg} / \mathrm{ml})$ & $363.92 \pm 602.05$ & $186.76 \pm 82.50$ & 2.965 & $0.049^{* *}$ \\
TF $(\mathrm{pg} / \mathrm{ml})$ & $335.36 \pm 88.61$ & $249.36 \pm 86.61$ & 4.705 & $0.003^{* *}$ \\
$30-39$ years & $82.03 \pm 54.21$ & $66.69 \pm 21.47$ & 1.932 & $0.001^{* *}$ \\
tPA $(\mathrm{pg} / \mathrm{ml})$ & $\mathrm{n}=99$ & $\mathrm{n}=33$ & & $0.049^{* *}$ \\
PAI $(\mathrm{pg} / \mathrm{ml})$ & $360.92 \pm 602.05$ & $183.76 \pm 82.50$ & 2.975 & \\
TF $(\mathrm{pg} / \mathrm{ml})$ & $345.05 \pm 153.31$ & $259.36 \pm 88.61$ & 4.715 & 0.310 \\
$40-49$ years & $80.04 \pm 54.21$ & $64.70 \pm 21.47$ & 1.922 & 0.253 \\
tPA $(\mathrm{pg} / \mathrm{ml})$ & $\mathrm{n}=90$ & $\mathrm{n}=30$ & 1.019 & 0.179 \\
PAI $(\mathrm{pg} / \mathrm{ml})$ & $354.75 \pm 313.34$ & $253.20 \pm 55.66$ & 1.148 & 1.353 \\
TF $(\mathrm{pg} / \mathrm{ml})$ & $411.65 \pm 349.88$ & $284.00 \pm 45.02$ & & \\
\hline
\end{tabular}




\begin{tabular}{lllll}
\hline Variables & Obese $(\mathbf{n}=\mathbf{3 1 2})$ & Normal $(\mathbf{n}=\mathbf{1 0 3})$ & t-test & p-value \\
\hline & Mean \pm SEM & Mean \pm SEM & & \\
\hline $50-59$ years & $\mathrm{n}=48$ & $\mathrm{n}=18$ & & 0.383 \\
tPA $(\mathrm{pg} / \mathrm{ml})$ & $229.83 \pm 82.54$ & $192.50 \pm 20.21$ & 0.887 & 0.382 \\
PAI $(\mathrm{pg} / \mathrm{ml})$ & $265.92 \pm 64.30$ & $295.00 \pm 5.77$ & -0.890 & 0.263 \\
TF $(\mathrm{pg} / \mathrm{ml})$ & $74.54 \pm 20.05$ & $62.50 \pm 14.43$ & 1.144 & \\
\hline
\end{tabular}

**Signaficant $(\mathrm{p}<0.01) *$ Signaficant $(\mathrm{p}<0.05) \dagger$ Not Signaficant

Evaluation of procoagulant factors among obese male and obese female subjects shows no significant difference in values of tPA, PAI, and TF among obese male compared with female obese subjects at $p>0.05$ as shown in table 3 below.

Table 3. Mean \pm SEM of tPA, PAI, and TF values among obese male and obese female subjects.

\begin{tabular}{llll}
\hline Parameter & Obese male $(\mathbf{n}=111)$ Mean \pm SEM & Obese female $(\mathbf{n}=\mathbf{2 0 1})$ Mean \pm SEM & t value \\
\hline tPA $(\mathrm{pg} / \mathrm{ml})$ & $282.84 \pm 45.70$ & $302.15 \pm 40.33$ & -0.222 \\
PAI $(\mathrm{pg} / \mathrm{ml})$ & $357.47 \pm 57.70$ & $345.22 \pm 29.59$ & 0.182 \\
TF $(\mathrm{pg} / \mathrm{ml})$ & $82.89 \pm 13.48$ & $86.97 \pm 7.39$ & $0.856 \dagger$ \\
\hline
\end{tabular}

** Significant $(\mathrm{p}<0.01) *$ Significant $(\mathrm{p}<0.05) \dagger$ Not Significant

\section{Discussion}

This study focuses on evaluation of TF, PAI, tPA levels in adult with obesity in Sapele and its environs.

Obese subjects had significantly higher levels of tissue Plasminogen Activator (t-PA) antigen when compared with normal weight subjects. This implies that, the level of plasma tissue Plasminogen Activator Antigen increases with excessive weight gains, which is in agreement with the reports of Vincent Ricchinti in 2006 [6], who observed that, obese subjects were characterized by higher concentration of antithrombotic factors such as, tissue plasminogen activator antigen (tPA) when compared with normal weight subjects. The increased level of tPA can be attributed to a protective response partly counteracting the increase in the prothrombotic factors in obese individuals. The increase value of t-PA among obese people in this study is in contrast with the reports of Kobayashi et al., in 1990 [7] and Singh et al., 2012 [8] who, showed that the level of tPA had negative correlation with obesity. However, there was no gender difference $(\mathrm{P}>0.05)$ in values of tPA in obese when compared with control subjects in this study and the reason for this result is not yet clear.

Furthermore, obese subjects had significantly higher values of Plasminogen Activator Inhibitor (PAI) antigen when compared with normal weight subject. Again, this implies that, plasma PAI levels increases with weight gains. This is in line with earlier reported by previous researchers [7-10] whose findings showed that, PAI level correlates strongly with increased visceral accumulation of adipose tissue. This is suggestive that PAI may be an adipose derived circulating peptide. It is believed that transforming growth factor- $\mathrm{B}_{1}$ significantly increased PAI antigen production by adipocyte fraction and adipose tissue appears to be the major cells associated with PAI synthesis. There are strong suggestions that human adipose tissue especially visceral tissue in particular can be a main source of elevated plasma PAI levels seen in obesity. Also, in obesity associated with elevation of PAI, available evidence has points to TNF- $\alpha$ as vital indicators of PAI expression in adipose tissue and according to Hou et al., in 2004[11]. Studies by Alessi and others indicated, that, TNF- $\alpha$ as a main regulator in the obesity is associated elevation of PAI expression in adipose tissues [12].

In addition, people with obesity in this study had significantly higher plasma Tissue factor (TF) levels when compared with normal weight subjects. This implies that excessive weight gain also leads to elevated plasma tissue factor levels in obese subject. This result is in line with the findings of Hoffman in 2007 [13], indicating that coagulation activation following tissue factor upregulation in fatty body is common in obese subjects, Hoffman report further stated that, inflammation and metabolic alteration increases $\mathrm{TF}$ expression in adipocytes and macrophages in the obese subjects. Nevertheless, there was also no gender difference in TF values in this study.

\section{Conclusion}

The study noted that obesity induces alteration of tPA, PAI and TF values in all individuals irrespective of gender. Significantly higher values in tissue Plasminogen Activator antigen (tPA) Tissue Factor (TF) and Plasminogen Activator Inhibitor (PAI) antigen levels at $\mathrm{P}$ $<0.01$ were obtained in people with obesity when compared with normal or non-obese people in Sapele Southern Nigeria.

\section{Disclaimer}

The views expressed in this article are that of the authors not an official position of any hospital or institution.

\section{Conflict of Interest}

There is no conflict of interest regarding this work among the authors. 


\section{References}

[1] World Health Organization. (2015). Health effects of overweight and obesity in 195 countries over 25 years obesity calibrator. England Journal of medicine 377 (1): 13-27.

[2] Barness, L. A., Opitz, J. M and Gilbert, E. (2007). Obesity: genetic, molecular and environmental aspects. American Journal of Medical Genetics. 143 (24): 3016-3034.

[3] Haslam, D. W and James, W. P (2005). Obesity. Lancet. 366 (9492): 1197-1209.

[4] Lau, D. C., Douketis, J. D., Morrison, K. M., Hramiak, I. M., Sharma, A. M and Ur, E. (2007). Canadian clinical practice guidelines on the management and prevention of obesity in adults and children summary. Canadan Medical Annual Journal. 176 (8): 1-13.

[5] Faber, D. R., De Groot, P. G and Visseren F. L. (2009). Role of adipose tissue in haemostasis, coagulation and fibrinolysis. Obesity Review. 10 (5): 554-563.

[6] Vincent, Ricchinti, (2006). Obesity and Inflammation and Thrombotic Factors. Obesity and cardiovascular Disease. 13 (978): 14200-18905.

[7] Kobayashi, Y., Nihon, R. I., Fukou, Y., Shibuya, T and Terashi, A. (1990). The correlation between the activity of tissue plasminogen activator (TPA), levels of tissue plasminogen activator inhibitor (PAI) antigen and serium lipids in healthy subjects. Internal medicine. Rubmed. 27 (5): 578-583.
[8] Singh, A., Foster, G. D., Gunawardana, J., Mccoy, T. A., Nguyen, T., Vander, V. S., Komaroff, E. and Rao, A. K. (2012). Elevated Circulating tissue factor VII and plasminogen activator inhibitor in childhood obesity: evidence of a procoagulent state. British Journal of Hematology. 158: 522527.

[9] Sudi, K, M., Gallish, S., Weinhandi, G., Mainteau, W and Borkenstein, M. H. (2000). Relationship between plasminogen activator inhibitor 1 antigen, leptin and Fat mass in obese children and adolescents. Metabolism. 49 (7) 890-895.

[10] Azza, M., Ahmed, N. A., Shdai, H. R., Nehal, S. H., Nevine, E. S and Amany, A. A. (2013). Plasminogen activator inhibitor I in children with central obesity: Effect on left ventricular function. Journal of the Saudi Heart Association. 25 (2) 108.

[11] Hou, B., Eren, M., Painter, C. A., Covington, J. W., Dixon, J. D., Schoenhard, J. A and Vaughan, D. E. (2004). Tumor necrosis factor alpha activates the human plasminogen activator inhibitor-1 gene through a distal nuclear factor kappaB site. Journal Biology Chemistry. 279: 18127-181236.

[12] Alessi, M. C., Morange, P. and Juhan-Vague, I (2000). Fat cell function and fibrinolysis. Hormone and Metabolic Research. 32: 504-508.

[13] Hoffman, M., Colina, C. M., McDonald, A. G., Arepally, G., Pedersen, L., Monroe, D. M. (2007). Tissue factor around dermal vessels has been bound factor VII in the absence of injury. Journal of Thrombosis and Hemostasis.: 1403-1408. 